The Journal of Society and Media, April 2020, Vol. 4(1) 91-132

https://journal.unesa.ac.id/index.php/jsm/index

E-ISSN 2580-1341 and P-ISSN 2721-0383

Accredited No.36/E/KPT/2019

DOI: 10.26740/jsm.v4n1.p91-132

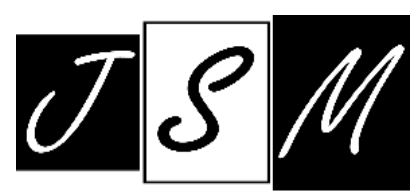

\title{
A Geopolitical Study of the Indo-Pacific through the Theories of Ancient East and Modern West
}

\author{
Praveen Kumar $^{1 *}$ \\ ${ }^{1}$ Department of Political Studies, Central University of South Bihar, India \\ SH-7, Village-Karhara, Post. Fatehpur, Gaya, Bihar, India \\ Email: praveenkr@cusb.ac.in
}

\begin{abstract}
The core of the debates on politics through times and regions is concerned with territories and exercise of power over the territories directed towards certain end(s). This is seen in the theories of Ancient India, of which Kautalya's Arthashastra is but a representative literature. Much later in time, geopolitical theories in the west during the twentieth-century significantly highlighted this point. This study aims to understand geopolitics in the Indo-Pacific if Kautalya's ideas and geopolitical choice theories from the west are applied, then results of the study would be the same as has been affirmed in the opening sentences. Methodologically, the study, qualitative in approach though, looks at the data available in the secondary source materials to test if territories determine the power dynamics at a given point of time. Kautalya's Arthashashtra offers a good theoretical insight that can explain the contemporary geopolitical structures and behavior of the states. The theory has scientific and empirical elements that can help explain issues of aggression, conflict and peace. Peace (Shamah) and conflict or war (Vigraha) are shaped by the inter-dependent factors, both, tangible and intangible, as well as, internal and external. While the study primarily explores "the empirical" and "the scientific" in Kautalya's Arthashashtra, but takes the twentieth-century western geopolitical theories to develop parameters of testability of the theory.
\end{abstract}

Keywords: kautalya, kautilya, india, geopolitics, indo-pacific

\begin{abstract}
Abstrak
Inti dari debat tentang politik selama ini banyak berkaitan dengan wilayah dan kekuasaan atas wilayah yang diarahkan pada tujuan tertentu. Ini terlihat dalam teoriteori India Kuno seperti Arthashastra Kautalya, yang dalam hal ini dianggap merupakan literatur yang representatif. Jauh di kemudian hari, teori geopolitik di barat selama abad kedua puluh menyoroti poin ini secara signifikan. Penelitian ini bertujuan untuk memahami geopolitik di Indo-Pasifik jika ide-ide Kautalya dan teori-teori pilihan geopolitik dari barat diterapkan, maka hasil penelitian akan sama seperti yang telah ditegaskan dalam kalimat pembuka. Secara metodologis, penelitian ini bersifat kualitatif, yaitu dengan melihat data yang tersedia dalam bahan sumber sekunder dan menguji apakah wilayah menentukan dinamika daya pada titik waktu tertentu. Arthashashtra Kautalya menawarkan wawasan teoretis yang bagus yang dapat menjelaskan struktur geopolitik kontemporer dan perilaku negara. Teori ini memiliki elemen ilmiah dan empiris yang dapat membantu menjelaskan masalah agresi, konflik, dan perdamaian. Perdamaian (Shamah) dan konflik atau perang (Vigraha) dibentuk oleh faktor-faktor yang saling bergantung, baik yang berwujud maupun tidak berwujud, serta internal dan eksternal. Sementara penelitian ini utamanya mengeksplorasi hal yang bersifat "empiris"
\end{abstract}

Submitted: 2020-02-04; Accepted: 2020-04-14; Published: 2020-04-25

*Corresponding author: Email: damedereba@gmail.com 
dan "ilmiah" di Arthashashtra Kautalya, tetapi mengambil teori geopolitik barat abad kedua puluh untuk mengembangkan parameter testabilitas teori.

Kata Kunci: kautalya, kautilya, india, geopolitics, indo-pacific

\section{INTRODUCTION}

The ideas of Kautalya contain elements of geopolitics which can serve the theoretical purpose by way of offering explanations to the pattern of inter-state behaviour and inclination of a state to adopt peace or war as its manifest policy. Spelling the name of the author of the Arthashashtra as 'Kautalya' is preferred over 'Kautilya' in the light of the explanation offered by Mahamahopadhyaya $\mathrm{T}$. Ganpathi Sastri who states that the name Kautalya was derived from Kutala that was his Gotra (clan) name. Of course, Kautalya wrote in a different time and 'Indo-Pacific' as a geopolitical construct would not be his reference point. However, Kautalyan views on politics are relevant to the understanding of geopolitical developments in the Indo-Pacific. Kautalya's ideas help in understanding the 'essence of politics' that deals with composition of power relationships in the international system. The behaviour of states would be shaped by the relationships of power (Das 1945). Significantly, Kautalyain his work has highlighted that geographical arrangement of states exhibits a pattern and interstate behaviour can be inferred by understanding the pattern. A detailed explanation of this aspect would be offered in the following sentences (Hidayat 2017). Kautalya's Arthshastra, meanwhile, merits consideration because it can transcend in time even if some authors believe, incorrectly though,that there is a lack of "historical sense" and "empirical concreteness" (Modelski 1964) in Kautalya'sArthashastra. This is to be understood in the light of the fact that Arthashastra represents an important phase in Indian history marking the emergence of a great empire highlighting the significance of politics and territorial identity. Secondly, Kautalya has endeavoured to offer theoretical generalisations concerning issues of politics that possibly remains the focus of study even today. Economics, social structures, military science, etc. are integral part of politics, according to Kautalya. In addition, Arthashastra is also a valuable guide for the rulers/governments and practitioners of the art of politics. Arthashastra is a kind of study that reflects empirical study of the contemporary political organisations and 
institutions to achieve theoretical generalisations on various aspects of kingship (government) and state, taxation, inter-state relations and international politics and trade, among others (Xiaotong 2019).

Kautalya's understanding of politics, in many ways, is the forerunner to the various theoretical streams in the disciplines of international politics/relations, peace and conflict studies/resolution, public policy and security and strategic studies, among others that may correctly be understood as the sub-branches of political science. The various internal and external factors, which may otherwise be inter-dependent as well, affecting the functioning of a state lead to conditions that may result in war (Vigraha) and/or peace (Shamah), and a ruler by studying carefully those conditions may choose a suitable policy. The Arthashashtrahas sufficient material that can be useful in terms of understanding those conditions and adoption of a suitable policy. Geopolitics, thus, can be studied and put into practice in the background of theoretical and practical guidance that comes from Kautalya's ideas enumerated in the Arthashastra. In terms of giving insights to the geopolitical happenings at the given time the contents in the Arthashashtra are rich through out. In fact, Books (Adhikaranas) VI and VII can especially be focused for this purpose. It is with special reference to these two books in the Arthashashtra that this paper makes a modest attempt to explore some of the contemporary themes in the discipline of geopolitics (Watanabe 2018).

As part of this endeavour, the focus has been made on the 'core issues' in the discipline of geopolitics. The core issues need to be understood by looking at the factors of geography. The process through which the geographical elements become important in making a power dominant in the international system is integral to this understanding. The control over human resources, land and/or water may play a significant role in this regard that has been examined by western geopolitical thinkers like Nicholas J Spykman, H J Mackinder and Alfred Thayer Mahan (Mackinder 1904; Spykman 1944; Mahan 2016).Internal and external factors may bring about changes in the existing pattern,in addition, and these changes at a given point of time may push a particular geopolitical region to rise in significance. Samuel Barnard Cohen has studied this aspect by taking the rise of East Asia as a case and China as a dominant player in this new geostrategic realm. Focus of the discourse, generally, is on a state's capabilities to influence 
and shape the politics in each region or to prevent another potential power toshape the happenings in its 'sphere of influence'.

The understanding of the factors that may lead to conflict or war in either case becomes important is novelty of research. This takes the investigation to stage or level where the focus is on understanding the causal factors that may lead to conflicts or wars.

\section{METHODS}

It would require a careful review of the relevant or select literature out of which the parameters required for such an understanding have to be abstracted. The objective, among others, is to establish that an ancient literature like Arthashastra has scientific and theoretical validity. This would require that this work of Kautalya's be made the centre of this study. Further, the abstraction may be done with an aim that the chosen terms or concepts could be quantified and their relationship could lead to testing the statement that power dynamics in the international system is, generally, territorially determined. This kind of method is novel in a sense that it would traverse the established pattern of collecting data in the light of given/selected concepts, but would absorb the empirical and scientific out of the secondary literature into the study. Elaborated, it would mean selection of potentially quantifiable parameters present in a literature that had been produced thousands of years ago, and again re-search the same among some of the literature that came later and which may be younger at least by 2500 years, and then finding, by superimposition of the earlier selected parameters on the latter, some common pattern after establishing their common identity in the light of current geopolitical happenings. The process may not be linear, but would involve the actions elaborated in the preceding sentence.

In light of the above, it is interesting to note that the developments in one of the what has been termed earlier as sub-branches of political science (is also called as sister disciplines), Peace and Conflict Studies have largely focused on the identification of factors and conditions, which if carefully managed may result in the absence of war or prevention of conflicts. Peace may also, alternatively, be understood positively. Here, it is not a state of non-existence of war or conflict, but a condition, which "denotes the simultaneous presence of many desirable states of mind and society, such as harmony, justice, equity, etc". 
Security, overall, becomes the aim that is to be realised for the object of peace in its broad dimension. Security is understood in its diverse form and multi-layered structure that may include understanding of the term at the level of individual and the community, on the one hand. At the national, regional and international level, this has to be understood, on the other side. However, this is not a segmented form in which security may exist, but it is associative-ness or inter-connectedness that forms the holistic understanding of security. Thus, in addition to the physical security, in its broader dimension, security includes a positive understanding that would enable the persons to enjoy their lives. The study, this way is focused to identify the role of actors, state and none-state and other inter-dependent factors in understanding the larger goal of security that a state may endeavour to achieve, but they are conditioned in the last instance by the considerations of territory (Ram 2015).

It is understood here that the focus in various literature that has been surveyed for the purpose of this study, primarily has been to understand conflict. Peace, too, possibly has been understood through the prism of conflict. The debate, in other words, has always been governed by the philosophy, which has maintained that defining or understanding peace in its own right or peace that may be intrinsic to the social existence or the psyche of the individuals is a delusion. Peace is understood as nothing but a temporary condition where conflict is missing. In the field of inter-state relations conflict is at best managed. In such conditions as is marked by this art of management of conflict, states can try to achieve their other goals, but the primary function, eventually; of the state is maintenance of security. There are theories, on the other hand, and some of them have been touched upon in the following sentences that have given space to cooperation and inter-dependence in the analysis, but they too have given importance to the role of conflict in inter-state relations and intra-state interactions. Individual level variables have been given place in order to analyse conflict and understanding the possibilities to achieve conditions of peace. It has been argued, for instance, by Johan Galtung and his colleagues that the right understanding of conflict may come when one understands the nature of violence connected with the structures that operate at various levels. They characterised the understanding of peace as absence of conflict or absence of violence or organised 
violence that prevailed in the literature as mainly negative in nature. The research should focus, in its stead "the sum total of other relatively consensual values in the world community of nations" like freedom from fear and want and of action, cooperation, equality, justice, economic growth, absence of exploitation, dynamism and pluralism that would be positive peace, properly understood (Modelski 1964).

The field of study, thus, has been dominated by efforts to identify variables operating at several levels that may generate conflict or produce conditions of 'peace'. Arthshashtra of Kautalya contains elements that would help in selecting variables in order to predicate conditions of conflict or war, as would be shown in the following sentences with the help of some of the contemporary examples of the existing affairs of the things between two or more states. An explanation may be required here. One, Kautalya belonged to a different time and the context in which he produced his work was, of course, different. The political organisation which formed the state during his time had pre-dominantly a monarchical form of government, the distinction between state and society was not clearly marked and the relationship of people with the state and the government was not shaped by such factors as people's participation in decision making that is considered to be a significant factor which goes into making a state or government. However, Kautalya clearly identifies the constituting elements of a state and the role and functions it may have especially in terms of the foreign policy making and defence strategy. Thus, concepts and definitions that might have been applied to explain the events in the ancient Indian society may find its application in contemporary times. Two, the contemporary research in the field of geopolitics and international relations gives more emphasis on empirical data and relies to a great extent on the use of technology. This is required to be put in perspective when the contents in Kautalya's Arthashashtra are analysed. Elements in Kautalya's Arthshashtra are understood to be based on empirical data to the extent that generalisations were made by Kautalya through his study of the social and political organisations at that point of time in Indian history. An evidence of empirical proof in the form of data in a compiled form, of course, has not come down to us. A lot of gap may possibly be due to the oral traditions of the form of knowledge that was practiced in ancient India. However, application of Kautalya's thought in the practice of statecraft during $3^{\text {rd }} / 4^{\text {th }}$ century BCE is 
certainly an evidence. Use of logic, reasoning and selection of operational parameters need to supplement the research efforts to understand the scientific elements in Kautalya's Arthashastra than searching only for empirical data. It may sound a general statement, but this possibly would be the case with most of the ancient literature across the nations. The responsibility is on the contemporary research to identify the scientific and empirical in the latter. In addition, lack of historical reference may have to do more with the kind of oral tradition of knowledge that was being followed in the ancient Indian society. Finally, the study has been done with an objective to bring forth the significant elements in the Arthashastra that can be used by the discipline of geopolitics for the benefit of mankind, and study and research to help enrich the discipline (Saeed 2017).

\section{RESULTS AND DISCUSSION}

The concept of peace needs to be defined and understood in terms of its connection with conflicts and war, and cannot be understood in its own right. The endeavour is to present the concept in a manner where the debate can be simplified and the concept can be understood in a given context where conditions of war/conflict may exist and the society facing these conditions desires to move towards the conditions where peace may be possible. The idea is not to understand the varieties that can be attached to the two concepts of war/conflict and peace. Various societies may have their specific experiences connected with conditions of conflicts and the approach the former might have applied to move towards the conditions of peace, and this is why it is significant to highlight this point. Thus, resolving conflicts do not stand independent of the context in which it needs to be understood. However, the unique experiences need to be factored into while a generalisation to understand conflict or peace is being understood. This is Kautalya's Arthashastra acquires significance even in contemporary times.

At this juncture the study would like to focus on the contemporary debates that dominate the geopolitical world. It is pertinent to note that India's rise and assertion of China with a possible intention to claim the dominant power status dominate the geopolitical themes, especially when one looks at the regional geopolitics. The One Belt One Road (OBOR) initiative of China and world view of India as a rising power in the region are the two issues which can be examined 
to understand the emerging scenario. The focus, thus, would be drawn further on the geopolitical construct that is emerging and gaining currency as "Indo-Pacific". "Indo-Pacific" could be understood with reference to the following characteristics:

Sitting atop strategic trade routes linking the West with East Asia, India is the fulcrum of a region spreading from Bab-al-Mandab and the Straits of Hormuz through the Malacca and the South China Sea to Australia and the Western Pacific. The wider Indo-Pacific region, spreading from India to the Western Pacific, is home to over 3.5 billion people, with a combined Gross Domestic Product of over $\$ 20$ trillion. It has three of the four largest economies in the world, i.e., China, Japan and India, and a substantive part of the world's seaborne trade, including that required for food and energy security (Singh 2014).

The important aspect related to the concept of this construct as the most significant contemporary development is the potential of the region to influence the geopolitical happenings across the globe, even as the demarcation that has been done in the preceding sentences may only be indicative. India and China have emerged as and the two potentially could influence the happenings of the world politics. The territory that a state may have under its command, either directly or through exercise of its influence in the whole process is important. To study this aspect the underlying spatial arrangement and significance of geography needs to be examined closely and they may, in fact, come in as tools of analysis. The western geopolitical thinkers of twentieth century have given significant considerations to the role of geography and the arrangements in which spaces may exist to influence the happenings of the world, which has been stated above. Geographical distances have been overcome over the years with new developments in the field of communication technologies and this has made the nation-states to have access to different geographical locations and this can also happen with little difficulty depending upon the technology and inter-dependence operating in the international system at a given point of time. Included in this are rise of information age as part of the larger process of globalization that has made cross-border interaction and movement of people, products and capital significantly easy. However, territory, both land and maritime and the state's desire to control territories directly or through some means that may allow 
exercise of influence continue to shape the behavior of the nation states. These aspects have been dealt with in a subsequent section (Hu 2020).

There is no denying the fact that the existing literature in the field of geopolitics and international relations contains significant knowledge that may help analyse the material causes of war and conflict, motives that may result in conditions of conflict or war and even war strategies of a nation. This paper, however, highlights that theory contained in Kautalya's Arthashastra was much ahead in time in terms of the understanding of the relationship between politics and war and the strategies to deal with wars. Kautalya, as would be explained below, had very clearly identified the conditions in which a state ismore likely remain at peace with another state. Also, the literature offers a clear understanding of the conditions when a state may decide to go for war against the other state. In addition, he understood that a state's power may depend upon its military and economic capability, but real power of a state is an outcome only of a sound policy adopted by it. Thus, war, peace or alliance can be predicted on the basis of spatial arrangement of the states, their economic and military capability and ability of the state/ruler to adopt and execute a sound policy. For the purpose of this study, as has been mentioned above, books VI and VII of Arthashastra have especially been focused upon to highlight these points. The study has used the Sanskrit version that was compiled and edited by Mahamahopadhyaya $\mathrm{T}$. GanapthiSastriand the English translation of Arthashastra that was done by Dr. R Shamshashtri.

It would be relevant here to stress that some theories have dominated the field of conflict studies during the modern times. It is pertinent to look at some of them before going into the literature of Arthashashtra. The former, following Jack S. Levy, can be summarised as follows. Levy has categorised one of them as system-level theories (Levy 2011). This theory has found its effective expression among the 'realists'. These theories believe that nation states primarily rely on power as a means to pursue their foreign policy objectives and the former primarily may even consider "pursuit of power" as the end. There can be inadvertent and deliberate wars among the nations. This happens, according to the system level theories due to the uncertainties in the international system as the latter is composed of unregulated nation-states. Nation-states can hope to achieve 
some form of balance of power. This balance of power may operate in a bipolar or multi-polar system, among others. It was debated that possibility of occurrences of war would be less in a system that would be stable. Realist thinkers including Kenneth Waltz and, earlier Hans Morganthau have argued in favour of a bi-polar system. Meanwhile, theorists like David Singer and Karl Deutsch were in favour of a multi-polar system in this regard (Waltz 2000; Deutsch 1964). Nonetheless, in either case it is only a temporary condition of absence of conflict or conflicts in the international system.

The second category belongs to what Levy has called the dyadic-level theories. The latter have given attention to the factors that may involve contests over territories between or among the states. Territorial issues, in these theories, matter more than other issues that may be reasons of conflicts between/among the states. War, however, is considered not to be a sufficient means to resolve the conflict of interests. There may be other factors which may explain the decision of a state to go for war and they include "private information and incentives to misrepresent that information, commitment problems and indivisible issues" (Levy 2011). Democratic peace theory belongs to the state-level theories, which argues that wars are most unlikely among the democracies. Kenneth Waltz, a realist himself, however, has contended that the democratic peace theory is untenable (Waltz 2000). On the other hand, the advocates of democratic peace theory like Michael W. Doyle have argued that "constitutional, international and cosmopolitan sources" together can connect "the characteristics of liberal polities and economies with sustained liberal peace" (Doyle 2005). Yet there are individual-level theories that pay attention to "the belief systems of key decision makers, the psychological processes through which they acquire information and make decisions, and their personalities and emotional states".

It can be stated that study and analysis of conflict and peace in the theories that have been mentioned above takes place in terms of the relationship of one with the other. Peace researchers, the leading figure among them being Galtung have endeavoured to understand 'peace' as something which "in itself be peace productive, producing a common basis, a feeling of community in purpose that may pave the ground for deeper ties later on" (Galtung 1969). According to Galtung, "violence is present when human beings are being influenced so that their actual somatic and mental realizations are below their potential realizations". 
Galtung has accepted himself that it is possibly a complex definition. Various distinctions have also been made by Galtung that include those between psychological and physical violence, positive and negative approach to influence, if there is a subject that acts, if there is an object that is hurt, intended and unintended violence and manifest and latent violence. However, violence needs to be explained and understood in all its dimension in order to address the issue of peace.

Galtung, as has been discussed in the paragraphs above, has attempted to approach the subject matter of peace in a manner to emphasise that peace should not negative, but positive. The global trends, however, indicate that conflicts continue to dominate the scene of world politics. The global political developments indicate that military expenditure has continued to increase over the years. This means that countries continue to factor in the issue of conflict in their approach to international politics. Higher military expenditure is seen with respect to the developing/developed countries, both. According to Stockholm International Peace Research Institute (SIPRI) military expenditure database the top developing/ developed countries in military spending in the year 2018 include Saudi Arabia, France, the United States, India and China 2019. The number of conflicts and fatalities in the latter, in addition, has not stopped. On the contrary, in many instances and in different regions, in fact, it is increasing. According to the Uppsala Conflict Data Programme (UCDP), in various organised conflicts during the year 2018 more than 77,000 persons were killed 2020. Even though casualties in systematic violence are reported to have "decreased for the fourth consecutive year", these assessments indicate that the world continues to face conflicts and resultant casualties occurring out of those conflicts. The studies are, nonetheless, valuable contributions in the field of peace studies and conflict resolution. Here, it also needs to be emphasised that the data as mentioned above relate only to 'organised violence'!

The point that this study explores in the following pages is the fact that Kautalya'stheory may help develop tools/techniques to understand and explain conflicts of the kind mentioned in the preceding sentences. This would help also building theory to weave the statistical findings of the above studies with the theories. The former help categorise conflicts but theory building and causal 
explanations based on theories can happen in the light of the factors that Kautalya had identified in Arthashastra.

Ideating contemporary geopolitics in arthashashtra. Kautalya's Arthashashtra provides an enormous and fruitful knowledge on the issues that contribute to conflicts in a state or between/among the states, as has been stated (Barnes 2011). With reference to the likely internal conflicts, Kautalya has identified the psychological and physical factors. He has, in addition, also explained that there are specific conditions in which a state would be inclined more to prefer peace than conduct war against the other state. It has also been discussed in the Arthashastra that given the relative capabilities of the states and their geographical position certain elements can be identified that can tell us if a state is more likely to wage war, enter into alliance or negotiate peace. Kautalya, however, does not maintain that peace can prevail in its own right. According to him, peace should be taken as a condition, which depends on some other conditions that need to be fulfilled. The conditions on which peace itself may depend upon includes the character of the ruler, nature of the ministers in the council that the King has engaged, character of the people who live in the state, the resources that the state may have, the foreign policy of the state depending upon the number of friends or enemies the state has, and the internal conditions of an enemy state, among others. At the base of inter-state politics, according to Kautalya, is the geographical position of different states and it is interesting to note here that the arrangement in which the states may be found to be existing at a given point of time becomes the point of reference to understand the inter-state relations, for Kautalya.

The theory of concentric circles, popularly known as Mandala Theory in ancient Indian literature is well known, and that has been very effectively presented by Kautalya in Arthashastra. In fact, the discipline of political science has discussed, analysed and researched the issue extensively (Bisht 2020; Shahi 2019; Singh 2005; Mehta 2018; Brown 1959). I intend, however, to highlight that inherent also is the idea of conflict and peace in the theory of Kautalya and the latter in many ways could anticipate the analysis of modern realist thinkers in which conditions or absence of conditions of conflict were identified. Also, the idea in the dyadic level theories that "most wars are between contiguous states" and "territorial disputes are far more likely to escalate to war" can also be found in 
Kautalya'sArthashashtra. Kautalya's Mandala Theory or theory of concentric circles offers an insight to understand the geo-locational elements that may help predict the type of relationship a state may have with the other. If a state, as indicated above, would be hostile to another state or is likely to seek protection of another state or would stay neutral or observe peace can be inferred based on the study of the conditions arising out of spatial arrangement that may be in operation at a given point of time.

This can be understood by referring to the definitions and explanations of the concepts that Kautalaya has given in Arthashastra. Kautalyahas identified the ruler or King whose state may be at the centre of the whole arrangement. Described as what he calls विजिगीषु: (Vijigishu), he states thatthe territorial arrangement that exists at a given point of time can be explained by placing the Vijigish $u$ at the centre and nature or attitude of other rulers/states can be made out by looking at their positions in the whole arrangement.As stated by Kautalya:

“राजाआत्मद्रव्यप्रकृतिसम्पनोनयस्याधिष्ठानंविजिगीषुः |”(Modelski 1964)

Meaning, "Vijigishu is the king who possesses good character and best-fitted elements of sovereignty". Vijigishuis also the source of policy. But, the king should have qualities to make him a good ruler. These qualities were elaborated by Kautalya in the Chapter I of Book VI. In addition to the qualities of a good king, Kautalya also describes the nature of territory that the state should have, the kind resources that the state should possess and the like. These details that are given in Arthashstra are very similar to the explanations that we come across in the field of study and research in geopolitics and international relations as physical and psychological factors which help in our understandingconflicts/war or the conditions of peace. As stated above, the geographical positions of states in themselves could be an indication of the nature of relationship between and among the states. In the words of Kautalya:

\section{तस्यसमन्ततोमण्डलीभूताभूम्यनन्तराअरिप्रकृतिः।}

$$
\text { तथैवभूम्येकान्तरामित्रप्रकृतिः। (Kautalya 1924) }
$$

In the paragraph above in samskrit, Kautalyastates that the relationship between the states that have common boundaries are likely to be inimical in nature. It 
requires to be added that Kautalya is referring to the inimicalnature of the relationship of contiguous states. Meanwhile, the state/ king that is situated close to the enemy, but not sharing boundaries with the Vijigishu is likely to be of friendly nature. Kautalya, then goes on to explain the nature of inter-state relations by linking it to the spatial arrangement in which the states are placed at a given moment. In the Figure 1 given below, which is only representative in nature, the likely spatial arrangements in Kautalya's thought have been graphically presented.

Figure 1

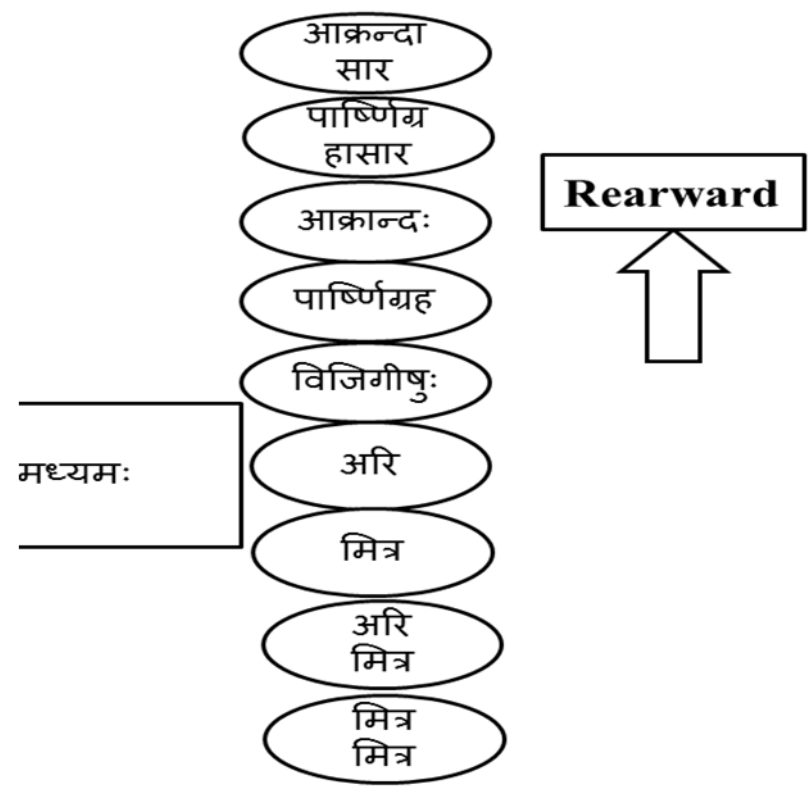

उदासीनः

Graphical Representation of Kautalya's Views of States' Spatial Arrangements

Meanings of the terms used in Figure I are as follows:

Vijigishu (विजिगीषु: ) = the King or the conqueror; Mitra (मित्र) = Friend;

Ari (अरि)= Enemy; Shatruh (शत्रु:)=Enemy; Ari Mitra (अरिमित्र)= Enemy's

Friend; Mitra Mitra (मित्रमित्र) = Friend's Friend; Madhyamah (मध्यमः)=Mediatory King; Parshnigraha (पाष्ण्णिग्रह)= Rearward enemy;

Parshnigrahasaar (पाष्णिग्रहासार) = Ally of the rearward enemy; 
Aakrandah (आक्रान्दः) = Rearward friend; Akrandasara (आक्रन्दासार) =

Ally of the rearward friend; Udasinah (उदासीनः) = Neutral king.

Stated in simple words, there is a fundamental idea that runs all through in the theory of concentric circles that was presented by Kautalya. This relates to the importance of territory over all the other issues that concerns two or more states. Hence the states situated at the periphery of each-other are unlikely to be friends. By implication, the conditions between two contiguous states may not be that of peace. This does not mean that there has to be incessant conflict or war between/among the states that share common borders. Some form of balance, in its stead, can be expectedto exist among the states where friend's friend is unlikely to be an enemy and enemy's friend is unlikely to be a friend. Zones of conflict and zones of peace, from the point of view of geopolitics, can be geolocated.

Kautalyahas also outlined the causes that may shape the inter-state relations and the resultant conditions of peace and/or war/conflict between or among the states or kingdoms. The territorial identity of the states could be referred to as kingdoms during the ancient Indian times. However, in this paper, states and kingdom has been used interchangeably. Such causes can be human or providential. Human causes can be anticipated, but the providential causes are unforeseen (Modelski 1964). A state's policy can be understood in this light, and a desired result can be achieved through the means of a policy. The Vijigishu, as stated above, is the fountainhead of policy. Hence, a king is likely to govern his state under peaceful conditions if the king can run the affairs of his state according to policy. In the act of administration the king who can run his state according to policy needs to give importance to property and security (of property). The emphasis in Kautalya's theory of politics is acquisition of territory and protection of what has been acquired. Eventually, peace and industry would ensure property and security. Kautalya has explained this as follows: 


\section{शमव्यायामौयोगक्षेमयोर्यानिः।}

\section{कर्मारमभाणांयोगाराधनोव्यायामः।}

\section{कर्मफलोपभोगानांक्षेमाराधनःशमः।}

\section{शमव्यायामयोर्योनिःषाड्गुण्यम्। (Kautalya 1924)}

Summary of the Samskrit passage given in the above paragraph in English would be as follows: Industry (vyayama) is an act that is done to achieve something and if such conditions exist as would ensure undisturbed enjoyment of fruits of vyayama (industry) then it would mean presence of a condition of peace. Differently stated, industry means that people of the state should be able to pursue various meaningful activities of their choice or what is expected out of them as part of their duty and the condition required for the enjoyment of the outcome of this industry is what can be called as the condition of peace. However, the internal conditions are not independent. This is also associated with what Kautalya has termed as six-fold policy in the field of inter-state relations. The latter include the policies that may lead to conditions of conflict or peace in inter-state relations. Thus, peace and industry both depend upon the six-fold policy. According to Kautalya,

तत्रप्रणबन्धः संधिः, अपकारोविग्रहः, उपेक्षणमासनम्अभ्युच्चयोयानंपरार्पणंसंश्रयः,

$$
\text { सन्धिविग्रहोपादानंद्वेधीभावइतिषड्गुणाः। (Kautalya 1924) }
$$

The above passage in Chapter I of Book VII describes the six forms of state policy as peace (संधिः or Sandhih), war (विग्रहःor Vigraha), neutrality (आसनor Aasana), marching (यानor yana), alliance (संश्रयःor Samshrayah) and waging war with one and making peace with another (द्वेधीभावorDwaidibhava). From among these six policies, a king/ruler can choose his policy, including those of concluding peace or waging war depending on the understanding of the situation and the king's assessment of the external and internal conditions and the relative capabilities of other states. While offensive operations mean war, according to Kautalya, peace between or among the states can be understood as agreement with pledges. Further, neutrality is indifference towards a state or an issue and marching means making preparations (for offensive action). Alliance 
would exist if a state seeks protection of another (strong) state. Dwaidibhava, as stated above would be the dual policy of simultaneous war with one and peace with another.

Kautalya's theory also provides an understanding of the condition of adoption of a policy by a given state. The conditions under which a policy or a combination of them would be followed, according to Kautalya, are as follows:

परस्माध्दीयमानःसंद्धीत।अभ्युच्चीमानोविगृहीयात्|नमांपरोनाहंपरमुपहन्तुंशक्त्ःइत्यासी

\section{त।गुणातिशययुक्तोयायात्|शक्तिहीनःसंश्रयेत।सहायसाध्येकार्येद्वैधीभावगच्छेत।}

(Kautalya 1924)

This means that while a state superior in power shall wage war, but the inferior state would adopt the policy of peace. Meanwhile, neutrality would be observed by a king that is confident of his capability. Kings who have necessary means may adopt the policy of marching (not an actual offensive action, but would possibly mean show of strength). Nonetheless, a state requiring defence, but lacking in necessary capability of its own would follow the policy of alliance, but the policy of Dwaidibhava would be pursued by the king/state that thinks that the dual policy of simultaneously waging war with one and making peace with another be in its interest. The capabilities are meant to vary over a period of time, and Kautalya factors in this aspect in his explanations. A state can grow or decline in terms of its capabilities and similar conditions may exist in an adversary state. While adopting a policy, the ruler can keep this aspect in mind. Also, the ruler is advised not to ignore the population of a state while deciding a policy with respect to the latter.Thus, the facets of power, according to Kautalya, are military and economic, but in addition to thishe puts a great emphasis on wisdom of the state/ruler (ideational power!) who is supposed to decide on and execute a policy. In his words,

शक्तिस्त्रिविद्याः (जानबलंमन्त्रशाक्तिः, कोषदण्डबलःप्रभुशाक्तिः, बिक्रमबलमुत्साहशाक्तिः।)

(Kautalya1924)

Now, Kautalya has explained these in detail in the Book VII of Arthashashtra. The core of the argument is that the eventual objective of a state is 
to ensure the welfare of the subjects. This has been very aptly put by Kautalya in the following sentence:

\section{बलंशक्ति:, सुखंसीद्धिः। (Kautalya 1924)}

What it means is, for a state, end is only happiness, even though strength of the state as has been outlined in the preceding sentences is the power of the state. It has been further explained that each state would endeavour to enhance its own power and elevate its happiness because possession of power and happiness becomes a benchmark for a state to find its place among the peers. Understood this way, this may capture the idea inthe modern geopolitical thinking as regards the behaviour of the state in the international system.

Kautalya's theories and geopolitics in the indo-pacific. In this section of the paper my endeavour would be understand the contemporary geopolitical structures with reference to Kautalya's ideas. With the help of Figure II below, I would try to demonstrate that the spatial arrangement in Kautalya's thesis can, to a great degree, find its applicability when we try to make out the geopolitical happenings on the political map of the Indo-Pacific region. For this purpose, I take the two countries as neighbours who share contiguous territorial boundaries in any form, land or maritime, or both. However, conflict over land borders between bordering countries appears to be prominent. In the next stage, I shall explain that the concerns of geopolitics that dominated the debate in the field in the past, continues to remain significant. A particular portion of geography continues to weigh in the strategic calculus of some powers more than other parts of the world. Also, the power that aims to achieve some significant geopolitical advantage at global level, also aims to see itself as a major world power. Here, the given geography may have its advantage. Else, the country may endeavour to bring under its influence that portion of geography that would bring it considerable geopolitical leverage against the competing powers at the global level. China's OBOR initiative has been taken to illustrate this aspect. To understand this, I shall try to blend the Kautalyan theory with the $19^{\text {th }} / 20^{\text {th }}$ century geopolitical theories of the west, which have been mentioned in the preceding sentences. 
Figure 2

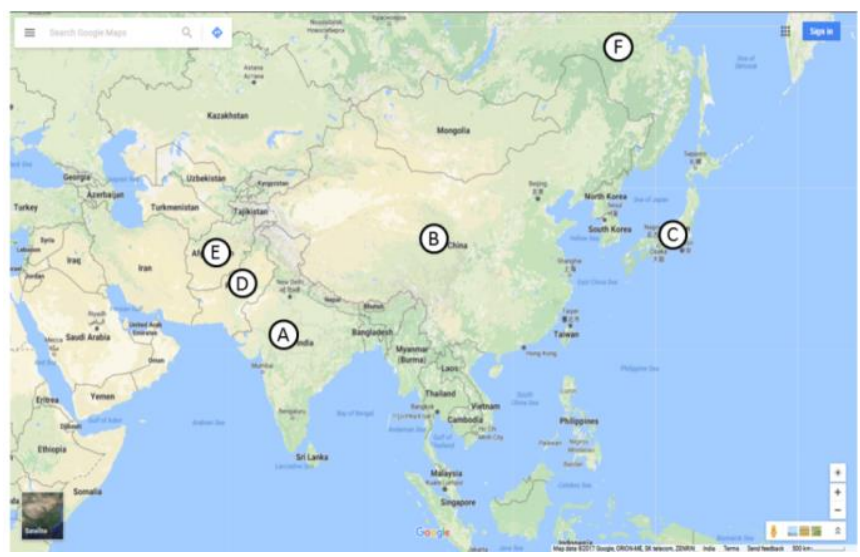

Geographical position of select states having common borders

(Source: Google Maps. Accessed on Jul 26, 2019.

https://www.google.co.in/maps/@30.3439595,99.915126,4z.)

The following countries have been illustrated in the above map- A: India, B: China, C: Japan, D: Pakistan, E: Afghanistan, and F: Russia

In the Table: 1 below, an endeavour has been made to see if the countries, which have been mentioned above have common borders and if they have a history of conflict.

Table 1

\begin{tabular}{ccc}
\hline Countries & Have common borders? & History of conflict \\
\hline India and China & Yes & Yes \\
India and Pakistan & Yes & Yes \\
Pakistan and Afghanistan & Yes & Yes \\
China and Russia & Yes & Yes \\
China and Japan & Yes & Yes \\
\hline
\end{tabular}

Countries with common borders and history of conflicts

The map and description above, both are illustrative in nature. The selection of the countries is random. However, the countries which have been shown on the map, their diplomatic relations with the neighbours have been of 
significant interest to the students of International Politics and Security Studies. This includes India-Pakistan-China relations, China-Russia relations and ChinaJapan relations, among others. Some of the details of China's relations with its immediate neighbours would follow in the subsequent sentences.

In addition, seen in the light of Kautalya's description, China lacks the necessary geographical and other conditions that are required for a state (kingdom) to enjoy sovereignty, in the complete sense of the term. Kautalya described that a state needs to possess requisite geography, in addition to the qualified council of ministers with a virtuous and righteous King as their head. Kautalya further stated that "The king, the minister, the country, the fort, the treasury, the Army and the friend" are the six elements of sovereignty. However, a state could enjoy sovereignty in the full sense of the term, if 'peace and industry' based on six-fold royal policy could be ensured by the king. Some of these debates would follow in the following paragraphs. At this stage, I intend highlighting that while no nation could be self-sufficient, and there could be issues that the nations may have to face during their evolution. However, as some of China experts like S B Cohen have pointed out, China faces a great deal of internal imbalance in terms of influence of geography and productive output (Cohen 2008). It is relevant to refer to Kautalya in this context, who stated that the troubles that a king may face could be internal or external. However, the internal troubles are more serious that external troubles. China's internal contradictions could require a delicate balancing act with outside world to avoid any major instability. It is in this light that China's diplomatic initiatives like OBOR could be contextualised. However, the paper makes an assertion that OBOR project of China also needs to be seen in the light of some of the recent, but influential geopolitical theories from the west. Thus, a blend of the ancient vision with the contemporary geopolitical constructs could provide some guide to the emerging geopolitical affairs in the Indo-Pacific. This I intend doing while taking the case of OBOR. Part of explanation has been provided with the help of Kautlayan thesis. In the following pages, endeavour would be made to apply some of the twentieth century western geopolitical theories to unravel the underlying geopolitical objectives that a country like China may have.

OBOR, perhaps, could be considered to be one of the most significant geopolitical issues in recent times. As would be known, the initiative includes 
Maritime Silk Road that was first articulated publicly by the Chinese premier Xi Jinping at the October 2013 summit of the Association of Southeast Asian Nations (ASEAN) in Indonesia. India, as a major actor in the region, continues to remain ambivalent in its approach on the issue (Mishra 2019). This ambivalence is due to the fact that China's intentions behind the proposal are believed to be much beyond than what have been articulated as the intended outcomes of the project, in terms of the benefits of commerce that the nation-states participating in the project may get. The reasons may be history of China's relations with India and other nations in Southeast Asia and East Asia. China's relations with Russia, at present, do not appear to be acrimonious, but certainly there is an element of uncertainty due to the competing interests both the nations may have in the Central Asian region. Also, both the countries do have a history of conflict over territorial issues. What complicates the matter is the intention of United States to continue to remain an important player in the region and the rising profile of India, where the latter and China are seen as competitors in the region. Internal dynamics of the Chinese society, which the Chinese Communist Party leaders feel may face instability due to increasing regional and class disparity in the regions of the North, Northeast and the interior and the regions of "Golden Coast" is yet another factor that needs to be considered while making any assessment of China's endeavour to bring economic gains for the Chinese people (Kang 2003).

The realistic assessment of China's involvement in the project cannot be made, until it is understood that there is the larger geopolitical objective to create a pattern of dominance, where China's interests are central to the global political activities. The projected economic structure at the surface, may, in fact, have the underlying geopolitical objectives that would establish China as a regional hegemon, first and in the subsequent stage or stages, eventually, as an acclaimed global power. The paper takes a view that this may be true for any nation-state, which at a point of time is in a position to significantly influence the international political, economic and strategic happenings with the power that the country has acquired over a period of time to nurture such an ambition. However, it depends on the country's ability and intentions to use its resources towards meeting those political objectives (Wang 2019). 
China and the OBOR. The Silk Road as a network of trade routes linking China with the regions of Central Asia, West Asia, Africa and Europe had existed during the ancient times. There are historical references to the revival of the route, during the seventh century, for instance. However, the current initiative of Chinese premier Xi Jinping is intended to bring China at the centre of world economy, and subsequently at the centre of world politics, as a consequence. The road, in Xi Jinping's scheme of things, refers to ancient maritime routes between China and Europe, and the belt depicts the overland trade route.

China's economic interests are primarily going to be served, globally, through the means of the proposed initiative. There are already evidences to this aspect. Chinese shipping company, Cosco, took a 67 per cent stake in Greece's second-largest port, Piraeus. Chinese firms are building a high-speed rail network linking Piraeus to Hungary and finally Germany. In addition to investment in Gwadar port and nuclear reactor in Pakistan, China has announced that it would finance highway and invest two billion dollars into a coal mine in the Thar desert and a hydropower station in Pakistan. According to a report in the Economist, during the first five months of 2016, majority of China's overseas contracts have been signed with nations along the proposed Silk Road (Pant 2016). The report contends that "Like a steam train pulling noisily out of a station, China's biggest foreign-economic policy is slowly gathering speed" (Cho 2019).

China-proposed OBOR still does not have an official list of member countries, but the number of countries associated with the Asia Infrastructure Investment Bank (AIIB) could be indicative. The AIIB website lists 102 members . China's State Information Centre has recently created Belt and Road Initiative Big Data Center. According to pakistantoday, Pakistan, Russia, Kazakhstan, Thailand and Indonesia are the top five countries actively cooperating with China on OBOR, and Russia among them is the top collaborator with China (2016). Some of China induced projects might have faced problems. China's proposed 3,000 km high-speed rail line from Kunming to Singapore is a case in point. Talks in June 2016 with Thailand over its section of the line failed. However, according to the AIIB approximately 70 projects have already been approved and close to 25 more have been proposed 2020. Many of the approved and proposed development projects belong to India. AIIB had been started with 100 billion dollars of initial capital, even thoughthe AIIB purportedly is not formally part of OBOR. An 
informal high-level body linking government and party organisations under Zhang Gaoli, a member of the Politburo Standing Committee had been given the responsibility to supervising the developments. China reportedly had earmarked 82 billion dollars with three of its state-owned 'policy banks' in 2015 for OBOR projects. In addition, China had also created a new Silk Road Fund worth $\$ 40$ billion. The reports indicate that 44 per cent of China's new engineering projects were signed with the countries in the proposed OBOR region in the year 2015, which rose 52 per cent in the first five months of 2016. With more investment in these countries, Chinese firms are also more likely to manage the infrastructure they build, making their presence longer in those countries (Ikenberry 2003).

OBOR: historical role for China or historical baggage. According to $\mathrm{Yu}$ Jie, China's ambition and its self-perception of middle kingdom complex possibly continues to remain a major factor shaping the psyche of the Chinese political and economic elite (Bisht 2020), even today. Historically, China has perceived itself as the centre of the world. Its perspective of centrality is, possibly, still evolving where China's looks at itself in a position that is centrally located between the Heartlandic and Maritime realms. This centrality is independent of and interconnected with the last two in matters of China's choice (Cohen 2008). China, for the most of its recorded history of approximately four thousand years appears to have practiced a sense of high degree of ethnocentrism and sought to wall itself off from outside world (Cohen 2008). However, maritime orientation was imposed on China during $19^{\text {th }}$ and early $20^{\text {th }}$ century and 19 different countries obtained unilateral privileges for control of treaty ports (Cohen 2008). Since 1949, however, the communist China was a closed and heavily rural system. Its geopolitical orientation was continental in nature and was oriented towards Eurasian Continental Realm.

Thus, during the $20^{\text {th }}$ century, China primarily emerged as a continental power. However, China had used the sea route in the past to spread its economic influence and establish its dominance in the littoral regions, including those of the Indian Ocean. The most famous official overseas expedition was the seven long distance cruises that had been undertaken by admiral Cheng-ho between 1405 and 1433. The fleet had visited ports from Malacca and Ceylon to Red Sea entrances to Zanzibar and compelled the "recalcitrant to acknowledge Peking". The fleet is 
believed to have included ships around 400 feet long and displaced over 1,500 tons. Subsequently, the continental threats and Chinese conservatism at that point of time appear to have compelled retreat of the expedition (Kennedy 1993).

China has again started looking towards the sea, once the continental threats appear to have receded. The relative decline of the US as a world power, USA's defeat in the Vietnam War and collapse of the Soviet Union appear to have added credibility to China's claim as a rising power, in addition to its sustained economic performances since 1980s and rising military profile. The Chinese political elite have always nurtured a dream to a great China, which has a worldclass economy and military. In addition, China also has sought to establish its sovereignty over Taiwan and other disputed islands in the South China and East China Sea. Following the end of the Cold War, the importance of a navy is being highlighted in making endeavours towards accomplishing their long cherished dream (Scott 2010).

China's increasing naval assertion. China's military officers have been more assertive about Chinese naval modernization since 1990s. This is being sought to be done through the acquisition of latest weapons and equipment and endeavour to develop a blue-water naval strategy, which is best exemplified in the doctrine propounded by Admiral Shi Yunsheng, Commander of the People's Liberation Army Navy (PLAN). The Chinese naval modernisation is sought to be accomplished in four stages that would include an offshore defence strategy; a technologically equipped strong navy with focus on scientific Research and Development (R\&D); more advanced weapon systems to the PLAN; and welltrained personnel and more qualified people (Hyung 1993). In addition, PLAN also intends to develop anti-submarine warfare (ASW) capabilities and spread its influence to the strategically significant Panama and Suez canals. Hong Kongbased Hutchison Whampoa Company took the rights to port facilities on both the Pacific and Atlantic terminals of the Panama Canal in 1997 and under an agreement with Egypt, ships of the state-owned China Ocean Shipping Company (COSCO) would use port facilities along the Suez Canal (Ibid). China has been modernizing its naval assets to implement its maritime expansion. The Table: 2 below shows development of China's submarine capabilities between 1997 and 2010 and is indicative in this regard. 
Table 2

\begin{tabular}{lccccc}
\hline & 1997 & 2004 & 2006 & 2008 & 2010 \\
\hline $\begin{array}{c}\text { Strategic (SSBN) } \\
\text { Xia class }\end{array}$ & 1 & 1 & 1 & 1 & 1 \\
Jin class & 0 & 0 & 0 & 2 & 2 \\
Tactical (SSN) & & & & & \\
$\quad$ Han class & 5 & 5 & 4 & 4 & 4 \\
$\quad$ Shang class & 0 & 0 & 0 & 2 & 2 \\
Tactical (SSG) & & & & & \\
$\quad$ Romeo class & 1 & 1 & 1 & 1 & 1 \\
Tactical (SSK) & & & & & \\
Kilo class & 3 & 4 & 3 & 12 & 12 \\
Ming class & 13 & 19 & 19 & 19 & 19 \\
Romeo class & 36 & 35 & 20 & 8 & 8 \\
Song class & 1 & 3 & 9 & 10 & 13 \\
Yuan class & 0 & 0 & 0 & 2 & 2 \\
Tactical (SS) & & & & & \\
Golf class & 1 & 1 & 1 & 1 & \\
Strategi submarines & 1 & 1 & 1 & 3 & 3 \\
Tactical submarines & 60 & 68 & 57 & 59 & 62 \\
TOTAL & $\mathbf{6 1}$ & $\mathbf{6 9}$ & $\mathbf{5 8}$ & $\mathbf{6 2}$ & $\mathbf{6 5}$ \\
\hline
\end{tabular}

China's developing submarine capabilities

China's naval technology may be substantially behind the current U.S. capability, but China is reported to be working in the direction of overcoming that gap. The U.S. has 11 aircraft carriers, while China has one, the Ukranian-built Liaoning. However, according to a recent report of US Congress, China has plans to grow its navy to 351 ships by 2020 . China is also reportedly indigenously developing aircraft carriers (Grinin and Grinin 2015). China has plans to acquire four aircraft carriers in near future. These include the LUYANG III, a new class of Chinese destroyer capable of carrying surface-to-air missile, among other weapons. China is also testing and developing a new, carrier-based fighter aircraft, the J-15. China is also planning to add amphibious assault ships to its fleet. Chinese modernization plans aim to raise the numbers of attack submarines and nuclear-armed submarines or SSBNs. According to the report, the exact 
amount of Chinese military spending is difficult to identify, China's defence spending for 2014 is approximately $\$ 131$ billion, which is 12.2 percent greater than China's spending in 2013. This figure is about one sixth of annual U.S. expenditure.

The Table:3 below is illustrious in this regard. I would help compare capabilities of three regional powers, India, USA and China. Some significant military and economic capability (select) parameters have been chosen to highlight this aspect. However, it is significant in this regard to note that Kautalya had attached a lot of significance to the wisdom of the leadership in applying the military or economic capability to achieve the desired the results. As Kautalya observes:

"a wise king, trained in politics, will, though he possesses a small territory, conquer the whole earth with the help of the best elements of his sovereignty (saptanga or seven elements) and will never be defeated"(Kennedy 1993).

Table 3

\begin{tabular}{|c|c|c|c|c|c|c|c|c|}
\hline \multirow[t]{2}{*}{ Country } & \multicolumn{4}{|c|}{ Military Capability (select) Parameters } & \multicolumn{4}{|c|}{$\begin{array}{c}\text { Economic Capability (select) } \\
\text { parameters }\end{array}$} \\
\hline & (1) & (2) & (3) & (4) & (5) & (6) & (7) & $(8)$ \\
\hline India & $3,462,500$ & 520 & 1 & 16 & $2,718,732$ & 66,510 & 3.7 & 6.8 \\
\hline USA & $2,141,900$ & 2,362 & 24 & 68 & $20,544,343$ & 648,798 & 36 & 2.9 \\
\hline China & $2,693,000$ & 1,222 & 1 & 76 & $13,608,152$ & 249,997 & 14 & 6.6 \\
\hline
\end{tabular}

Capability Comparison: India, USA and China

(1) Active Military Personnel; (2) Fighters; (3) Aircraft Carriers; (4) Submarines;

(5) National GDP in Million USD in the Year 2018; (6) Military Expenditure in Million USD; (7) Share of World Military Expenditure in per cent; (8) Growth Rate in the Year 2018

(Sources: Global Firepower Index 2020; SIPRI Database: 2020; WB Database: 2020)

The data which has been given above in Table: 3 need to factor in two things. The US continues to remain economically and militarily the strongest state. Meanwhile, India is the fourth largest military in the world, but economically the country was ranked 7 , according to the World Bank database. 
Also, while the USA may have rate of growth lower than that of India or China, but the country USA is a much bigger economy than the latter (Mattlin 2016).

Seen in the light of the data from previous years, it would appear that given the current level of development in China, its population size and demography, China still is looking for better prospects for itself. A comparison on the basis of some of the economic parameters with the United States, considered to be the only world power in today's context, despite seen relatively declining, would be in place. According to the World Bank data, China's overall GDP was 10.87 trillion dollars in 2015 and its GDP growth was 6.9 per cent in the same year (World Bank 2016). According to another report, China's share in world economy was 13.4 per cent in 2014, however, this was below to that of United States', which was 22.3 per cent. The GDP per capita in China in 2014 was 7,626 dollars, which was much below to that of the USA's, which was 54,360 dollars. The report stated that China already is the world's largest trading nation. In 2015, China's share in world trade was 4,068 billion dollars, which was more than the share of the US' in world trade, which stood at \$3724 billion. China has smaller proportion of city dwellers (54.4 per cent) in comparison to that of the US (81.4 per cent). However, the report estimated that China's GDP would overtake that of the US in 2026 with US growing at 2 per cent per annum, whereas China at 6.56.9 per cent per annum (Malcom and Sam 2016). China, however, is still developing its military capability to match that of some of the major powers of the world. Development in the field of naval capability, as discussed in the preceding paragraphs, is among them (Ejaz and Javaid 2018).

Continental-Maritime split personality and rising internal contradictions. China's performance in the economic field needs to be seen in the context of some of the unpleasant geopolitical realities that the nation has been facing in the recent times. The situation does not appear to have changed significantly, even now. China faces the issue of regional economic differentiation that is marked by "the emergence two entirely different systems of political economy"(Kennedy 1993). The different kinds of political economy, one is based upon inward oriented stateowned enterprises and centralised controls. The other, on the other hand, and the other had has been shaped upon the outward-oriented capitalism. At the same time, China also faces what S B Cohen has termed as Continental-Maritime split 
personality. The Continental orientation drives China to look more inwardly. However, the coastal areas under the influence of Maritimity are more outwardly orientated. Thus, the Continental-Maritime split personality of China has given it contrasting world orientations. It has retained its repressive, top-down communist bureaucratic apparatus, while encouraging a market oriented economy (Cohen 2008). These factors together have given rise to uneven regional development, widening class disparity in the regions of North, Northeast and the Interior and the Coastal areas and likely political instability (Agnew 2015).

Significant geopolitical developments like defeat of United States in the Vietnam War, collapse of Soviet Union, and rise of China as an economic power since 1980s has made China to emerge a significant regional player in what Cohen has characterized as the third geostrategic realm, the East Asian Geostrategic Realm, the other two being the Continental Realm and the Maritime Realm (Cohen 2008). The realm, according to Cohen, includes China, North Korea and the Indochinese geopolitical region including Vietnam, Laos and Cambodia (Cohen 2008). Following end of Maoism and Vietnam War and subsequent Deng era reforms, the 're-opening' of the economic system has led to uneven regional development. This has led Maritimely to become a feature in China's geopolitical characteristics. The coastal regions of Guangdong, Hong Kong, and Fujian to Zhenjiang, Shanghai and Jiangsu, which are called the "Golden Coast of China" have made China to emerge as an economic powerhouse. The Golden Coast comprises China's growing middle class and China's wealthy entrepreneurs. This area also has the country's highest per capita income and largest share of foreignfunded companies (Melander 2016).

Continental China, including the Country's North, Northeast and the Interior at the same time has the concentration of state-owned 'antiquated, largescale industrial structure' that contribute insignificantly in raising the income level of the population in the region (Cohen 2008). The reforms introduced during the regime of Deng Xiaoping gave incentives to the peasants. The land remained in collective ownership, but individual families were allowed to farm it as they desired. The families could sell the produce in the open market after delivering certain part of the produce to the community. This improved the agricultural output in the country (Kennedy 1993). However, agricultural resources are not enough to sustain the population in the region, which has led to the displacements 
of farmers to the cities. The centre of economic gravity has shifted to the Golden Coast, but the great majority of China's population and landmass are in the North and the Interior-from Manchuria to North China, to the outer provinces of Inner Mongolia and Xinxiang in the far West and China-controlled areas in the southwest, and the rural middle and upper parts of the Yellow and Yangtze River basins and southwest China (Cohen 2008). Northern and rural areas face frequent droughts and the growing urban centres, including Beijing face water shortage. According to Cohen, the Communist party, recognising dangers to political stability posed by the "underclass of the interior, where nearly 150 million people live on $\$ 1$ per day as well as the need to stem their flow to the already overcrowded coastal cities where they are an exploited labour class" declared to create a "socialist countryside" at the 2007 National Communist Party Congress. The declaration included a commitment to invest massively in rural development, land reform, clean water and improved transportation. The plan also includes building new urban city-regions with modernized industries in such interior cities as Chongqing, Chengdu, and Xian.

Kennedy in his book entitled Preparing for the Twenty-First Century in 1993 while comparing India and China showed that China contained $1 / 5^{\text {th }}$ of earth's population with only seven percent of its farmland, much of which was of poor quality. Population density was three times the world average. Kennedy observed, "For politicians and planners hoping that China will participate in the Pacific Rim 'boom' then, the threat that economic gains will be swallowed up by population growth is a real one" (Kennedy 1993). Kennedy quoted a demographer stating that China's population in 2035 will contain twice as many persons in their sixties as in their twenties. China's situation on population front has not much improved since then. China's population is 1.371 billion out of the world population of 7.3 billion as of mid-2015 (World Bank 2016; UN Department of Economic and Social Affairs 2015). While India and China both are likely remain the most populous country and India's population is likely to reach that of China's level by 2022 , India is set to become the youngest country by 2020 .According to the findings of the "State of the Urban Youth, India 2012: Employment, Livelihoods, Skills", a report published by IRIS Knowledge Foundation in collaboration with UN-HABITAT, every third person in an Indian city today is a 
youth. In about seven years, the median individual in India will be 29 years, very likely a city-dweller, making it the youngest country in the world. The summary of the report was published in The Hindu (Mahan 2016). In contrast, according to the census data released by China on 28 April 2011, China faces low birth rate and ageing of the population. The 2010 census of China showed that people above the age of 60 constituted 13.3 per cent of the total, which was up from 10.3 per cent in 2000. During the same period, the population under the age of 14 declined from 23 per cent to 17 per cent. Using this data, The Economist in its report concluded that "the trend of increasing aging population and declining number of youth and the people in workable age would continue in the coming times in China (Dellios 2017).

What appears that China has achieved some economic progress, where the foreign trade driven by the forces of Maritimity plays an important role. However, the split geopolitical personality of the nation and disparity in regional and class development, complicated by uneven population growth pose significant challenges to the nation, which may even affect the political stability of the nation and eventually its national integration. Through the ambitious OBOR project China may be endeavouring to address some of the issues, which have been discussed in the preceding paragraphs. However, there are significant geopolitical issues that go with the national personality of China, considering the mismatch between its economic status and its military status in the international political system on the one hand, and its desire to become the power to influence and control the world political activity as a major world power on the other. The historical self-perception of being the middle kingdom complex and desire to reclaim that status is one among them (Omoera 2019).

OBOR or strategy to be a regional hegemon. China perceived itself as a significant regional player in the $20^{\text {th }}$ century. Classical realist notion of balance of power would indicate that China has been involved in two forms of balancing act in the Asian region. The first one being the form of direct opposition that China was involved with Japan from 1931 to 1941 . The second kind is that of competition with the United States or Soviet Union for control of countries of Southeast Asia. Since the first century BC, the international status of Korea has by and large been determined either by Chinese supremacy or by rivalry between China and Japan (Singh 2014). Following the geopolitical developments since the 
last decade of the $20^{\text {th }}$ century, China now appears to look at itself not as factor in lending balance to the system, but as an actor, which owing to its size and rising economic capability can influence the international political developments in its interest (Pahrudin 2019).

The OBOR project is a step in that direction. However, initiative is also indicative of the continued significance of geography in international politics. Meaning, technology has achieved new heights in the present-day world and nation states face little challenge, apparently, on account of geographical distance. The remote geographical locations, too, can be accessed with little difficulty. The information age in an era of globalization claims that cross-border interaction and movement of people, products and capital have been made significantly easy by the present-day means of communication. However, as far as nation-states are concerned, territory and the ambition to have control over territories directly or through such means, which facilitates exercise of influence over the territory continue to shape their behaviour. A power with greater capabilities can do it more successfully. Geopolitical theorists during the $19^{\text {th }}$ and $20^{\text {th }}$ century have significantly debated how world domination could be achieved by controlling the critical mass of the globe. For Halford J Mackinder it was the Heartland (Jacob 2017).

"The conception of Euro-Asia to which we thus attain is that of a continuous land, ice-girt in the north, water-girt elsewhere, measuring 21 million square miles, or more than three times the area of North America, whose centre and north, measuring some 9 million square miles, or more than twice the area of Europe, have no available water-ways to the ocean, but, on the other hand, except in the subarctic forest, are very generally favourable to the mobility of horsemen and camelmen" (Mackinder 1904).

Mackinder accorded importance to continental power, and came up with the dictum that "Who rules East Europe commands the Heartland: Who rules the Heartland commands the World-Island: Who rules the World-Island commands the World."

In contrast, A T Mahan made a comprehensive historical analysis of role of sea power in achieving world dominance. A naval strategist, who is believed to 
have influenced American naval modernization programme, especially during Theodore Roosevelt's time, Mahan considered that the six elements, including geographical position, number of poppulation, national character, physical conformation, extent of territory and character and policy of governments were required to achieve preponderance over the sea. He concluded that a country like Great Britain could become the largest empire of the world primarily because it was a great sea power (Mahan 2016).

Given China's position and its contrasting world orientations, China requires to combine within itself the elements of continental power and maritime power, both. In fact, a careful understanding of OBOR would indicate that this is what China intends achieving through this project. In understanding this, ideas of $20^{\text {th }}$ century American geopolitical thinker, Nicholas J Spykman would be the most useful. In Spykman's opinion, it is the lack of systems of communications with a complete absence of industrial technique that has so far prevented China from effectively integrating its vast territories. Spykman considered that "size means potential strength". Along with the size, Spykeman believed that actual strength of a nation lies in technology and a will to power. After 50 years, he held, while writing in 1938 that "the quadrumvirate of world powers will be China, India, the United States, and the U.S.S.R (now Russia).” In his understanding (Jannah, Raudlatul, Handayani, Yuswadi, and Hidayat 2019)

"the geographic area of the state is the territorial base from which it operates in time of war and the strategic position which it occupies during the temporary armistice called peace. It is the most fundamentally conditioning factor in the formulation of snational policy because it is the most permanent. Because the geographic characteristics of states are relatively unchanging and unchangeable, the geographic demands of those states will remain the same for centuries, and because the world has not yet reached that happy state where the wants of no man conflict with those of another, those demands will cause friction. Thus at the door of geography may be laid the blame for many of the age-long struggles which run persistently through history while governments and dynasties rise and fall" (Spykman 1938).

However, Spykman's understanding of the Rimland is more significant in the case of OBOR. Mackinder's geographical concept of the "Heartland was 
accepted by Spykeman," but he believed that the coastal region bordering the "Heartland" that Mackinder had characterised as "inner or marginal crescent" was a crucial region of world politics. In the posthumously published work of Spykman, The Geography of the Peace, the former renamed the inner crescent as the "Rimland." Rimalandwas described by Spykman as follows:

"The rimland of the Eurasian land mass must be viewed as an intermediate region, situated...between the heartland and the marginal seas. It functions as a vast buffer zone of conflict between sea power and land power. Looking in both directions, it must function amphibiously and defend itself on land and sea." (Spykman 1944)

Countries of the Southwest Asia, Middle East, Western Europe and East Asia, including China are included in Spykman'sconcept of Rimland. These countries along with the offshore islands of Japan and Britain possess greater industrial and manpower resources than the Heartland. The Rimlandis composed of sea powerand the land power, both. Spykeman presented his dictum as:"Whocontrols the rimland rules Eurasia; who rules Eurasia controls the destinies of the world" (Spykman 1944). It would be illustrative to compare Spykeman's Rimland with that of the OBOR map. 
Figure 3

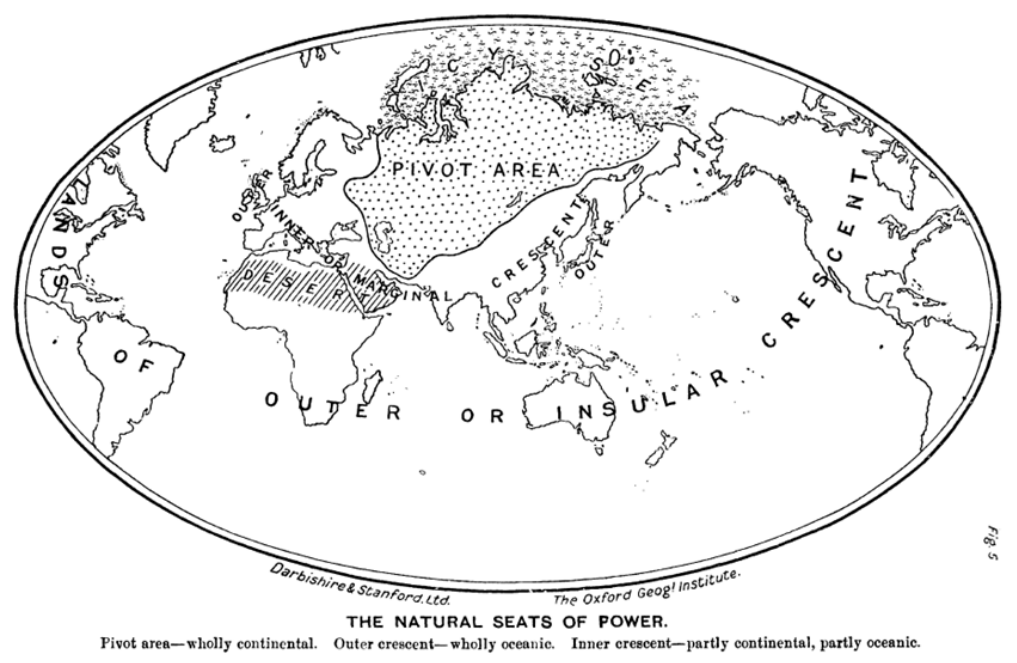

Mackinder's Tri-zonal structure

(Source: Mackinder 1904: 435)

As mentioned above, what Mackinder had called as inner or marginal crescent was termed by Spykman as Rimland, and in his opinion it was crucial to have control over the Rimland in order to have the world domination. The figure 2 below shows the areas that are sought to be covered under the OBOR project.

Figure 4

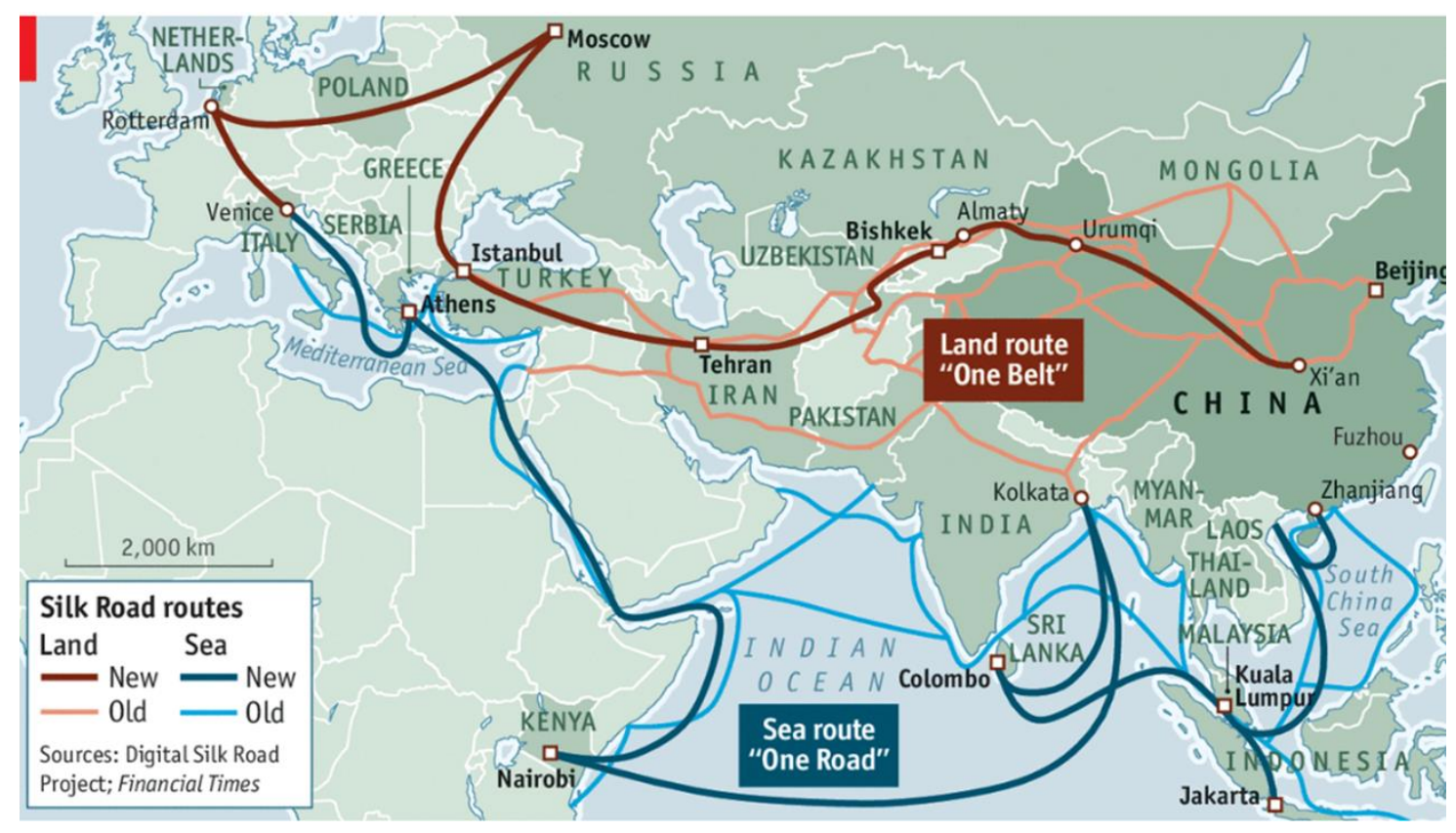

OBOR Route

(Source: http://www.economist.com/news/china/21701505) 
As the figure 2 indicates, the Silk Road routes that China seeks to cover under its OBOR project covers largely the area, which Mackinder had termed as inner crescent and Spykman as Rimland. The significance of Rimland, as explained by Spykman has already been discussed above.

India as a Maritime power in the Indo-Pacific region. India has maintained maritime connections with the outside world since ancient times. Ancient India had witnessed the use of Navy for military purposes. Use of Navy by Tamils against Ceylon during $2^{\text {nd }}$ Century $\mathrm{BC}$ is evidence. Naval connections even earlier than that could be traced to the first millennia BCE. Contacts with western Asia and Burma (now Myanmar) and use of ports for commerce and political purposes were also seen in the later period of the ancient Indian history. Southern kingdoms of Cheras, Pandyasand Cholascan also be mentioned here in this regard. Missionaries, colonisers and traders, all took the sea route to come to India during later part of Indian history.

India's maritime connections and related foreign policy issues in the contemporary period is centred on the Indian Ocean thatis identified, geographically, from the Cape of Good Hope to the Strait of Malacca. Indian Ocean is the link between the East and the West part of the globe. There are vital sea lanes of communication, including the strategic choke points in the Strait of Hormuz and the Strait of Bab-el-Mandeb in the Indian Ocean. India's 7,516.6 km long coastline in nine States-Gujarat, Maharashtra, Goa, Karnataka, Kerala, Tamil Nadu, Andhra Pradesh, Odisha and West Bengal, and four Union TerritoriesDaman and Diu, Lakshadweep, Puducherry and Andaman and Nicobar Islands are areas of challenges and opportunities, both. Ninety per cent of global commerce, today, takes place via sea route. Out of this trade flow, approximately50 per cent of the world's container traffic and seventy per cent of the total traffic of petroleum products pass through the Indian Ocean. The geographical location of the Indian coasts makes the latter strategic with respect to the movement of international shipping cargo, thus, making the role of Indian ports vital role in the overall economic development of the region. Approximately 80 per cent of the world's sea-borne oil trade passes through the choke points of this ocean. According to the statistics of the Ministry of Shipping, about 90 per cent by volume and 70 per cent by value of the country's international trade is carried on 
through maritime transport. Additionally, India's foreign policy since 1991 has been looking east, which aims, among others, at better economic ties with the countries located in Southeast and East of India. There might be alternative routes of transport, but in the light of the facts mentioned in the preceding sentences, it is understood that the maritime route would continue to remain predominant in commerce and trade with the East and Southeast Asian nations. This requires that policy initiatives pertaining to Indian coastal areas need to factor in aspects of national security and national economy, both.

Security of maritime borders is always considered important in conventional terms. However, two developments during the last two decadesoffloading of explosives used for the 1993 Mumbai serial blasts at Raigad coast and the terrorist incident of 26 November 2008 in Mumbai, sensitised the Indian security establishment for the requirements to reorienting the security setup to tackle the terrorist challenges to security coming through maritime route. In the national security environment, coasts of India matter beyond the conventional threats of state aggression from enemy countries to its territories through the sea routes. However, opportunities, too, have increased manifold when it comes to use of coastal resources for developmental activities. Sustainability is another factor that is of growing importance to any policy initiative. In this sense, any definitional endeavour would be considered limited in approach, if maritime strategy is taken to mean coastal security, and the latter in turn is taken to mean policing of coastal waters in terms of enforcement of such measures by the state police, in conjunction with and by other law enforcement agencies, including the Navy, the Coast Guard, CISF, BSF and Indian Customs department, among others to control and prevent illegal movement of goods and people. A holistic approach that appreciates development, including business in addition to security is what would be needed. Areas of foreign policy, commerce and finance, shipping and cargo movement, environmental sustainability and IT infrastructure must converge when India takes stock of security along its coasts. Thus, what would actually be required is a developmental approach to maritime security that would have preventive and protective model of countering organised crime and terrorist network as one among the various elements.

In this respect, the Maritime Doctrine of India, 2004 declares that India's legitimate area of interest in the maritime domain range from the Arc from Persian 


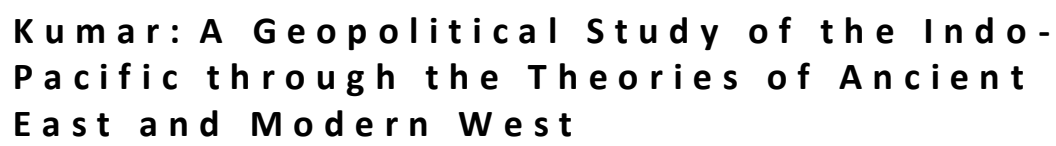

Gulf to the Strait of Malacca. In view of the above, this is pertinent to look at the Maritime Military Strategy of the Indian Navy that was outlined in a document entitled "Freedom to use the sea: India's Maritime Military Strategy" (Clinton 2011). According to the Indian Navy:

"(T)he main business of major navies in the $21^{\text {st }}$ Century is to use warships to support foreign policy by less violent methods. During the long years of peace, we need to project power and show presence; catalyse partnerships; build trust and create interoperability through combined operations, and international maritime assistance. The range of options available extends from unilateral armed action, or coercion, at one end of the spectrum of naval diplomacy to bilateral and multilateral defence cooperation at the other end."

India's maritime diplomacy, keeping in view these factors, are not reactionary to those of China's actions, what has been debated popularly in the strategic circles as China's 'String of Pearls' or 'encirclement' strategy. India has made meaningful engagements with the littoral countries. In the process, India has extended its friendship to the countries in the Indian Ocean and to the countries on her east, especially reaching out to the smaller littoral countries like the Madagascar, Sri Lanka, Maldives, the Seychelles and Mauritius. These countries too have shown confidence in India positive approach in the region. There could be potential issues between India and her smaller maritime neighbours, but they are occasional, like those of the fishermen with Sri Lanka. However, overall, India has also proved a useful partner for these countries in safeguarding their sovereignty and territorial integrity. The Southeast Asian countries and Japan too find it convenient to deal with India. Unlike China, these countries do not have any territorial issues with India, and countries like Singapore, in fact, welcome greater role for India in the region. In addition, regional naval powers like the US too are positive about India's capability to become a net provider of security in the region. Port calls to various navies in the region, and annual naval exercises including those with the US Navy are indicative of this fact (Rose 1998). 


\section{CONCLUSION}

Kautalya while dealing with the elements of sovereignty in his book the Arthashashtra prophesied बलंशक्ति:, सुखंसीद्धिः. It would mean, for a state, strength is power and happiness is the end. Kautalya also explains that strength is of three kinds and depending on the kind of strength a state has, corresponding happiness, could be of three kinds. Three kinds of strength mentioned in Arthashashtra are intellectual strength, strength of sovereignty (constituted of prosperous treasury and strong army) and physical strength (constituted of martial power). Corresponding ends respectively are those of deliberation, sovereignty and of martial power. Although there may be lack of consensus among historians and political scientists, but it is believed that the Arthashastra was written approximately two thousand and four hundred years ago. Still, the theoretical implications of Kautalya's work have continued to remain relevant for successive generations. Understood properly, military, economic and ideational, including technological powers determine national power, and the more of them a nationstate has, better its status in the international system. By implication, the more powerful a state is, more secure it is, in all aspects. Considering that the states in the current international system are inter-dependent and have to endeavour for the acquisition of strength and corresponding happiness in the international system, competition among the states is inevitable.

In the preceding paragraphs an endeavour has been made, briefly, to offer a glimpse of the ideas in Kautalya's Arthashashtra that would benefit the contemporary discipline of geopolitics. This is an outline of the ideas from geopolitical point of view that one may find in the Arthashashtra and which is relevant, too, in contemporary times. The focus eventually is on the ends that a state may seek follow which is about prosperity and happiness of the people of a state. Nonetheless, rivalry, conflicts or war is also considered to be integral to the understanding of geopolitical happenings. This requires a state to guard itself against any conspiracy or treachery by other states and, for this, the state needs to be powerful. Since there are threats, external and internal, the state that desires to be happier and more peaceful also needs to be more powerful than other states. Meanwhile, Kautalya does throw light on cooperation between the states. This very idea of mitra (friend) and ari (enemy) encapsulates the ideas of cooperation 


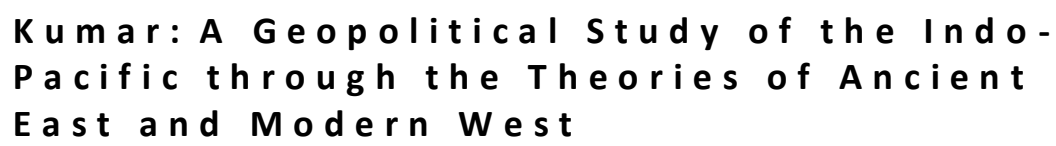

and conflict in the field of relations between and among the states. Finally, it can be underlined that the emerging geopolitical construct in the Indo-Pacific canbe seen in terms of the significance of geography to the inter-state relations, and the internal and external factors that Kautalya had enumerated in his Arthashashtraand the latter can be a significant guide to understand the emerging geopolitics of the contemporary Indo-Pacific.

\section{REFERENCES}

Agnew, J. 2015. "Revisiting the Territorial Trap." Nordia Geographical Journal and Publication 44:43-48.

Barnes, Donald Grove. 2011. "Indian and The Indian Ocean: And Essay on The Influence of Sea Power on Indian History. By KM Pannikar.” The Journal of Asein Studies", Volume 6 (1): 95-96,

Bisht, Medha. 2020. Kautalya's Arthashastra: Philosophy of Strategy. New Delhi: Routledge.

Brown, Donald M.. 1959. “The White Umbrella: Indian Political Thought From Manu to Gandhi." Journal of Political.

Cho, Il Hyun. 2019. "Dueling Hegemony: China's Belt and Road Initiative and America'a Free and Open Indo-Pacific Strategy." Journal of Indo-Pacific Affair 2(4).

Clinton, Hillary. 2011. “America's Pacific Century." Journal of Foreign Policy 189(1):56-63.

Cohen, S. B. 2008. Geopolitics: The Geography of International Relations. Lanham: Rowman and Littlefield.

Das, Taraknath. 1946. "Indian and The Indian Ocean: And Essay on The Influence of Sea Power on Indian History. By KM Pannikar.” The American Historical Review", Volume 51(2): 314-315

Dellios, R. 2017. "Silk Roads of the Twenty-First Century: The Cultural Dimension.” Journal of Asia Pacific Policy Study 4:225-36.

Deutsch, Karl W.;. David J. Singer. 1964. "Multipolar Power System and International Stability." Journal of World Politics XVI:390-406.

Doyle, Michael W. 2005. "Three Pillars of Liberal Peacee." Journal of American Political Science Review 99(3):463-66.

Ejaz, Khushboo and Umbreen Javaid. 2018. "U.S. Indo Pacific Policy: Response 
of Regional State.” Journal of Political Studies 25(2):157-75.

Galtung, Johan. 1969. "Violence, Peace and Peace Research." Journal of Peace Research 6(3):167-91.

Grinin, Anton L. and Leonid E. Grinin. 2015. "The Cybernetic Revolution and Historical Process." Journal of Social Evolution and History 14(1):125-84.

Hidayat, Medhy Aginta. 2017. "Ibadat, the Body and Identity: Islamic Rituals and the Construction of Muslim Identity." The Journal of Society \& Media $1(2): 1-18$.

$\mathrm{Hu}$, Wei. 2020. "Analysis of the Development Level of Geo-Economic Relations between China and Countries along the Belt and Road." Journal of Sustainability 12(8):1-21.

Hyung, Lee Jae. 1993. “China's Expanding Maritime Ambition in the Western Pacific and the Indian Ocean." Journal of Contemporary Southeast Asia 24(3).

Ikenberry, John. 2003. "International Relations Theory and the Asia-Pacific." Journal of International Relation 21-33.

Jacob, J. T. 2017. "China's Belt and Road Initiative: Perspectives from India." Journal of China World Econ 4:225-36.

Jannah, Raudlatul, Baiq Lily Handayani, Hary Yuswadi, and Nurul Hidayat. 2019. "Knowledge Construction In Ecological Sustainability Of The Women." The Journal of Society and Media 3(2):196-215.

Kang, David C.. 2003. "Getting Asia Wrong: The Need for New Analytical Framework." Journal of International Security 4:57-85.

Kautalya, Arthashashtra. Ed. T. Ganapati Sastri, T Mahamahopadhyaya. 1924. Trivendrum: Government Press.

Kennedy, Paul. 1993. Preparing for the Twenty-First Century. New Delhi: Indus.

Levy, Jack S. 2011. Theories and Causes of War. United Kingdom: Edward Elgae.

Mackinder, Halford J.. 1904. "The Geographical Pivot of History." The Geographical Journal 170(4).

Mahan, Alfred Thayer. 2016. "Influence of Sea Powers Upon History." Journal of Influence Sea Power 1660-1783.

Mattlin, M. and Mikael Wigel. 2016. "Geoeconmics in the Context of Restive Regional Powers."Journal of Asia Europan Geoeconomics 14:125-34.

Mehta, V. R. 2018. Foundations of Indian Political Thought. New Delhi: Manohar Publishers and Distributers. 
Melander, Erik. 2016. "Organised Violence in The World 2015: An Assessment." Journal of Oppsala Conflict Data Programme 61.

Mishra, Sitakanta. 2019. "Revision of India's Nuclear Doctrine Repercussions on South Asian Crisis Stability.” Journal of Indo-Pacific Affair 2(4).

Modelski, George. 1964. "Kautalya: Foreign Policy and International System in the Ancient Hindu World." Journal The American Political Science Review LVIII(3):549-60.

Omoera, Osakue Stevenson and Enuwa Evelyn Obekpa. 2019. "Neo-Colonial Dependence and Dualistic Development Models: An Exploration of the Development Communication Trajectory in Nigeria." The Journal of Society and Media 3(2):178-95.

Pahrudin, HM. 2019. "The Role Of The Merangin Regency Government Through Welfare Policy In The Globalization Era." The Journal of Society and Media 3(2):216-36.

Pant, Harsh. 2016. The Rise of the Indian Navy: Internal Vulnerabilities. New York: Routledge.

Ram, Vignesh. 2015. "The Proposal for an Indo-Pacific Treaty of Friendship and Cooperation: A Critical Reassessment." Journal of ASEAN Studies 3(1):2231.

Rose, Gideon. 1998. "Neoclassical Realism and Theories of Foreign Policy." Journal of World Politicss 51(2):144-72.

Saeed, Muhammad. 2017. "From the Asia-Pacific to the Indo-Pacific." Journal of International Studies China Quarterly of International Strategic Studies 3(4):499-512.

Shahi, Deepshikha. 2019. Kautalya and Non-Western IR Theory. New Delhi: Palgrave Macmillan.

Scott, Kennedy. 2010. "The Myth of the Beijing Consensus." Journal of Contemporary China 65(19):461-77.

Singh, G. P. 2005. Political Thought in Ancient India. New Delhi: D K Printworld.

Singh, Sanjay. 2014. "Indo Pacific: A Construct for Peace and Stability." Indian Foreign Affairs Jurnal 9(2).

Spykman, Nicholas J. 1938. "Geography and Foreign Policy." Journal of American Political Science Review 32(1).

Spykman, Nicholas J. 1944. The Geography of the Peace. New York: Harcourt, 
Brace and Company.

Waltz, Kenneth N. 2000. "Structural Realism after Cold War." Journal of International Security 25(1).

Wang, Sornarajah Muthucumaraswarmy;. Jiangyu. 2019. "China, India and International Law: A Justice Based Vision Between the Romantic and Realist Perceptions." Asian Journal Of International Law 9(2):217-50.

Watanabe, Atsuko. 2018. "Greater East Asia Geopolitics and Its Geopolitical Imagination of a Borderless World: A Neglected Tradition." Journal of Political Geography 67:23-31.

Xiaotong, Colin Flint;. Zhang. 2019. "Historical-Geopolitical Contexts and the Transformation of Chinese Foreign Policy." The Chinese Journal of International Politics 295-331. 